\title{
Regeneration of Virus-Free Plants by in Vitro Chemotherapy of GFLV (Grapevine Fanleaf Virus) Infected Explants of Vitis vinifera cv 'Zalema'
}

\author{
C.M. Weiland \\ E.P. Superior \\ University of Huelva \\ 21819-La Rábida \\ Huelva \\ Spain
}

\author{
M. Cantos and A. Troncoso \\ Instituto Recursos Naturales \\ y Agrobiología \\ CSIC \\ Sevilla \\ Spain
}

\author{
F. Perez-Camacho \\ E.T.S.I. Agrónomos y \\ Montes \\ University of Córdoba, \\ Córdoba \\ Spain
}

Keywords: acyclovir, ribavirin, Vitis vinifera

\begin{abstract}
In vitro chemotherapy using ribavirin or acyclovir was applied to eliminate Grapevine fanleaf virus (GFLV) from Vitis vinifera cv 'Zalema' plant material. Ribavirin at $20 \mathrm{mgl}^{-1}$ of concentration eliminated GFLV from the $94 \%$ of the grapevine in vitro shoots, enabling GFLV virus free plants to be obtained. The ribavirin treatment did not affect plant growth, rooting and number of roots, and did not cause chlorosis, hyperhydration or apex necrosis. Acyclovir at the same concentration was ineffective in regenerating GFLV-free plants and clearly negatively affected the explant development producing apical necrosis.
\end{abstract}

\section{INTRODUCTION}

Through the last years there has been a considerable increase in the knowledge of grapevine virus and virus diseases (Ribereau y Gayon, 1986; Pearson and Goheen, 1996).

Grapevine fanleaf virus Genus: Nepovirus (GFLV) is the most harmful and causes the most important economical losses in the vineyard (Bovey et al., 1980; RibereauGayon and Paynaud, 1986; Krastanova et al., 1995)

This RNA-virus occurs in all the viticultural areas of the world due to the good host conditions of grapevine cultivars and rootstocks and different transmission vectors. From ancient times it has been know that GFLV is transmitted through soil. Branas et al. (1946) related virus proliferation with the presence of plant losses. Arnaud (1937) related the disease with phylloxera attacks and Hewit et al. (1958) with Xiphinema index nematode. Other researches have associated the GFLV infection with nematodes, mainly $X$. index (Esmenjaud et al., 1994; Brown et al. 1995) and X. italiae (Cohn and Nitzany, 1970) and theses nematodes exist in almost Spanish vineyards (Arias et al., 1994).

The use of contaminated plant material for grafting is another way for the GFLV-virus is transmitted (Ravaz, 1960). ELISA test is probably the best and quick method to detect GFLV in grapevine plants (Vuittenez, 1980).

Thermotherapy is the traditional treatment for virus elimination, consisting in growing infected plants or shoots in a heat therapy chamber $\left(38-40{ }^{\circ} \mathrm{C}\right)$. After $35-60$ days new shoots sprout that can be removed and rooted. With this method 48-70\% of virus free plant can be reached (Goheen and Luhn, 1973; Monette, 1986; Wample 1997). Higher percentage of virus-free grapevine plants has been obtained by in vitro culture of apical meristem (Barlass et al., 1982) and Cantos et al. (1993) increased that percentage by combining both thermoterapy and in vitro culture. Another in vitro technique for generating virus-free plants from virus-infected plant material is the addition of antiviral chemicals to the culture medium. These substances have a negative effect on viral multiplication causing, as in thermotherapy, a different speed between shoot growth and virus infection resulting in free virus shoots. Nevertheless, some of the antiviral chemicals can be also phytotoxic, reducing growth and inducing chlorosis and apical necrosis, and even at high concentration can be lethal for plant. However chemotherapy offers reduction in energy costs (Monette, 1983) and enhanced genetic stability since differentiated plant material is used. 


\section{MATERIAL AND METHODS}

'Zalema' is the major cultivated variety in the 'Condado de Huelva' where it is used for the production of both ambar-liquor and young-table-white wines. 'Condado de Huelva' zone is situated in the SW of the province of Huelva (Andalusian, Spain).

Ribavirin (1-E-D ribofuranosyl-1,2,4-tiazol-3-carboximide and Acyclovir (2-amino1,9 dihydro-9- $z$-hydroxyethoxy-methyl@ $@$ H-purin-6-one) were compared for the in vitro obtention of GFLV-free 'Zalema' grapevine plants.

Severely GFLV-infected plants were selected by visual symptoms and vine-shoots collected. GFLV-infection of the vine shoots was checked by ELISA (Gugerli et al., 1984). Infected explants (10-15 mm of length with one bud) were prepared by cutting the infected shoots. Explants were disinfected first by a few seconds immersion in $70 \%$ ethanol followed by a second immersion $(20 \mathrm{~min})$ in $12 \%$ sodium hipochlorite $(3.5 \%$ active chlorine). The explants were placed individually in sterile test tubes with $10 \mathrm{ml}$ of VID culture medium (Troncoso et al., 1990). The tubes, covered with plastic caps and sealed with parafilm were placed in a growth chamber at $23 \mathrm{r}^{\circ}{ }^{\circ} \mathrm{C}, 30 \mu \mathrm{Em}^{-2} \mathrm{~s}^{-1}$ of light intensity and $16 \mathrm{~h}$ photoperiod, till plant formation (45 days). These plants were analysed again by ELISA test and new GFLV infected explants obtained and cultured: 36 in the above medium, 17 in the same medium plus $20 \mathrm{mg} \mathrm{L}^{-1}$ of Ribavirin and 46 in the same medium plus $20 \mathrm{mg} \mathrm{L}^{-1}$ of acyclovir. As control, 58, 9 and 57 non infected explants were in vitro grown on the three above media respectively.

The data were analysed statistically as follows: a) continuous data: ANOVA $(\mathrm{p}<0,05), \mathrm{b})$ categorical data: chi-square (Table $3 \times 2$ ) with hypothesis Ho: independence between lines and columns; when there is dependence the test $t$ it is applied among percentages.

\section{RESULTS AND DISCUSSION}

The influence of the two virocide chemicals on the ability to obtain GFLV-free shoots and on the plant development is shown in Table 1. Control and acyclovir treatments did not produce any free-GFLV shoot when GFLV-infected explants were used, indicating both a good transmission of the virus in the in vitro culture conditions and the inefficiency of acyclovir $\left(20 \mathrm{mg} \mathrm{l}^{-1}\right)$ DNA-virus virocide. On the contrary, ribavirin treatment to the infected explants, enabled $94 \%$ of GFLV-virus free shoots to be obtained, according to the virocide character of this compound to RNA viruses. Obviously, the non infected explants originate non infected shoots in all the cases.

In general, there was a higher plant stem growth of the non GFLV-infected explants than of the infected ones. This agrees with the results of Paneque (2000) and Troncoso et al. (2003) working with grapevine apical meristems. There was not a significant negative effect of ribavirin as compared to the control. On the contrary, acyclovir treatment had a negative effect on the stem growth mainly in the GFLV-infected plant material.

A similar behaviour occurred with rooting and number of roots that were very negatively affected by acyclovir, mainly when GFLV-affected explants were cultured (Table 1).

Acyclovir treatment also produced higher percentage of apical necrosis in the GFLVinfected plant material, but on the contrary less leaf chlorosis probably in relation to the very low plant growth.

There was not significant influence of the virocide treatments on the degree of hyperhydration of the plant tissues.

In consequence, ribavirin at $20 \mathrm{mgL}^{-1}$ of concentration, showed to be a good virocide to obtain GFLV-free grapevine plants of 'Zalema' cv. Also, ribavirin treatment did not affect the in vitro explant growth or rooting, except for some increase of leaf yellow chlorosis. This behaviour of ribavirin was in agreement with Stevenson and Monette (1983). These authors reported that rivabirin starts to be phytotoxic when used at concentrations of $40-50 \mathrm{mgL}^{-1}$.

In consequence, ribavirin treatments could be a good method for the in vitro obtention of GFLV-free virus plant of grapevine allowing the use of explants which are easier to 
propagate and with higher genetic stability than apical meristem.

\section{Literature Cited}

Arias, M., Bello, A., Fresno, J. 1994. Nematodos vectores de virus de la vid en España. Investigación Agraria. Producción y Protección Vegetales, 2:187-199.

Arnaud, G. 1937. Les maladies à virus des plantes. Progr. agric. vit., 106, 562-567; 107 , 35-38, 86-90, 110-113, 138-141.

Barlass, M., Skene, K.G.M., Woodham, R.C. and Krake, L.R. 1982. Regeneration of virus-free grapevines using in vitro apical culture. Ann. Appl. Biol. 101: 2191-295.

Bovey, R., Gärtel, W., Hewitt, W.B., Martelli, G.P., Vuittenez, A. 1980. Maladies à virus et affections similaires de la vigne. Atlas en couleurs des symptômes. Ed. Payot. Lausanne, Paris. $181 \mathrm{pp}$.

Branas, J., Bernon, G. Et Levadoux, L. 1946. Ëlements de viticulture générale. E.N.S.A. Montpellier.

Brown, D.J.K., Robertson, W.M., Trudgill, D.L. 1995. Transmission of viruses by plant nematodes. Annual Review of Phytophatology, 33: 223-249.

Cantos, M., Liñán, J., Pérez-Camacho, F. Troncoso, A. 1993. Obtención de plantas selectas de vid, variedad Zalema, libres de la virosis "entrenudo corto". Actas de Horticultura. Vol. II, 705-709.

Cohn, E., Nitzany, F. 1970. Xiphinema italiae, a new vector of Grapevine fanleaf virus. Phytopathology, 60: 181-182.

Goheen, A.C., Luhn, C.F. 1973. Heat inactivation of viruses in grapevines. Revista di Patologia Vegetale, 4 (9), supplement, 287-289.

Gugerli, P., Brugger, J. Et Bovey, R. 1984. L'enroulement de la vigne: mise en évidence de particules virales et développment d'une méthode inmunoenzymatique pour le diagnostic rapide.Revue suisse Vitic. Arboric. Hort. vol. 16 (5):299-304.

Esmenjaud, D., Abad, P., Pinck, L., Walter, B. 1994. Detection of a region of the coat protein gene of grapevine fanleaf virus by RT-PCR in the nematode vector Xiphinema index. Plant Disease, 78 (11): 1087-1090

Hewitt, W.B., Raski, D.J., Goheen, A.C. 1958. Nematode vector of soil-borne fanleaf virus of grapevines. Phytopathology, 48: 586-595.

Krastanova, S., Perrin, M., Barbier, P., Demengeat, G., Cornuet, P., Bardonnet, N., Otten, L., Pinck, L. Walter, B. 1995. Transformation of grapevine rootstocks with the coat protein gene of grapevine fanleaf neposirus. Plant Cell Reports, 14 (9): 550-554.

Monette, P.L. 1983. Virus eradication through in vitro techniques. Proc. Int. Plant propag. Soc., 33: 90-100.

Monette, P.L. 1986. Elimination in vitro of two grapevines viruses by an alternating temperature regime. J. Phytopath. 116: 85-91.

Paneque Macías, P. 2000. Estudio de factores físicos y biológicos de la zona viticinícola Aljarafe Alto (Sevilla). Tesis doctoral. Departamento de Cristalografía, Mineralogía y Química Agrícola. Universidad de Sevilla.

Pearson, R.C. and Goheen, A.C. 1996. Plagas y enfermedades de la vid. The American Phytopathological Society. Ed. Mundi-Prensa.

Ravaz, L. 1960. Le court-noué. Progr. agric. vit., 33, 694-703.

Stevenson, J.H. and Monette, P.L. 1983. Delay of onset of leafroll symptom expression in Vitis vinifera "Liemberger" from ribavirin-treated in vitro cultures. Can. J. Plant. Sci. 63: 557-560.

Ribereau-Gayon, J. and Paynaud, E.1986. En tratado de Ampelografía, Ciencias y Técnicas de la viña. Tomo II.368-397.

Troncoso, A., Villegas, A., Cantos, M. 1990. Growth and mineral composition of grapevine rootstock cultured in vitro with different levels ammonium nitrate. Plant nutrition, Physiology and applications. Kluwer Publishers. Holanda. pp 581-584.

Troncoso, A. Paneque, P., Cantos, M., Weiland, C.M., Pérez-Camacho, F. and Paneque G. 2003. GFLV-infection and in vitro behaviour of infected plant material of three typical Andalusian grapevine cvs. $1^{\text {st }}$ ISHS Symposium for grapevine growing, 
commerce and investigacion. Lisboa.

Vuittenez, A. 1980. The new improvements of serological methods and their possible application to detect and identify viruses and virus-like diseaes of the grapevine. Proc. $7^{\text {th }}$ Meet. ICVG. 8-12 Sept. 1980, Niagara Falls, Canada, p. 225-244.

Wample, R.L. 1997. Influence of pre- and post-treatment storage on rooting of hot-watertrated cuttings of Cabernet Sauvignon. Am. J. Enol. Vitic. 48 (2): 131-136.

\section{$\underline{\text { Tables }}$}

Table 1. Influence of chemotherapy treatments on the in vitro GFLV-cleaning up and development of 'Zalema' grapevine plant material

\begin{tabular}{lcccccc}
\hline & \multicolumn{3}{c}{ Infected explants } & \multicolumn{3}{c}{ Non infected explants } \\
Parameters & Control & Ribavirin & Acyclovir & Control & Ribavirin & Acyclovir \\
\hline Total explants & 36 & 17 & 46 & 58 & 9 & 57 \\
GFLV-free shoots (\%) & 0 & 94.1 & 0 & 100 & 100 & 100 \\
Plant stem growth (mm) & $37.6 \mathrm{a}$ & $30.5 \mathrm{a}$ & $5.7 \mathrm{~b}$ & $45.5 \mathrm{a}$ & $36.1 \mathrm{a}$ & $28.1 \mathrm{ab}$ \\
Rooting (\%) & $25.0 \mathrm{ab}$ & $17.6 \mathrm{~b}$ & $0 \mathrm{c}$ & $39.6 \mathrm{a}$ & $33.3 \mathrm{a}$ & $29.8 \mathrm{ab}$ \\
Number roots/plant & $0.26 \mathrm{ab}$ & $0.20 \mathrm{ab}$ & $0 \mathrm{c}$ & $0.75 \mathrm{a}$ & $0.30 \mathrm{ab}$ & $0.78 \mathrm{a}$ \\
Apical necrosis (\%) & $55.5 \mathrm{~b}$ & $32.5 \mathrm{c}$ & $80.4 \mathrm{a}$ & $30.8 \mathrm{c}$ & $55.5 \mathrm{~b}$ & $54.4 \mathrm{~b}$ \\
Leaf chlorosis (\%) & $41.6 \mathrm{~b}$ & $94.4 \mathrm{a}$ & $15.2 \mathrm{a}$ & $55.2 \mathrm{~b}$ & $100 \mathrm{a}$ & $42.1 \mathrm{~b}$ \\
Hyperhydration $(\%)$ & $22.2 \mathrm{a}$ & $11.8 \mathrm{a}$ & $21.7 \mathrm{a}$ & $17.2 \mathrm{a}$ & $0 \mathrm{~b}$ & $28.1 \mathrm{a}$ \\
\hline
\end{tabular}

